\title{
SUSTAINABILITY OF EDUCATION IN POST-PANDEMIC: CHALLENGES AND OPPORTUNITY
}

\author{
Aria Cakra Wibawa ${ }^{*}$, Bambang Suharjo² \\ ITNI Angkatan Laut, Jakarta, Indonesia \\ 2Sekolah Tinggi Teknologi Angkatan Laut, Surabaya, Indonesia \\ *aria3690@gmail.com
}

\begin{tabular}{l}
\hline Article Info \\
\hline Article history \\
Received March 29. 2021 \\
Revised May 4, 2021 \\
Accepted August 23, 2021 \\
\hline
\end{tabular}

Keywords: AHP; Education; Information System; PostCorona; SWOT

\begin{abstract}
The pandemic around the world has been going on for more than a year. A major impact in education has been the change from conventional education to online information technology-based education. After the pandemic, it was necessary to plan the educational model that was carrying out. To examine the educational model in the Indonesian Navy after the pandemic, a combination of SWOT - AHP will be carried out. The research subjects included five middle-ranking officers in the Indonesian Navy educational institution and the Indonesian Navy Education Office. The result of the research is that the Indonesian Navy needs to integrate the online-based education model with face-to-face education. Online-based education, especially in theory and face-to-face learning in the discussion model, workgroup, and teamwork in military team formations, platoons, company, battalion, and skills training in using the equipment. The global strategy compiled is an intensification of the combination of online and offline learning with an increasingly advanced educational information system, combining teaching materials and being equipped with increasingly qualified teaching staff from within the Indonesian Navy and others to improve Indonesian Navy education while maintaining system security and improve HR capabilities in the IT field by collaborating with other relevant agencies
\end{abstract}

\section{INTRODUCTION}

The pandemic due to the coronavirus attack from early 2020 until now has still hit almost all countries. The impact is very felt in the world of education. Implementation of online education must be implemented at all levels of education for a long time to date. The education system, which was initially implemented face-to-face with conventional learning methods, must be transformed into an online education method (Abidah et al. 2020; EspinoDíaz et al. 2020).

The impact of the pandemic is also very high at various levels of education, including in higher education (Rashid \& Yadav 2020), in military education ((Franchi 2020; Rawat, Boe, \& Piotrowski 2020). Education, which requires a lot of physical interaction, such as vocational higher education and military education, is severely affected, and other skill practices requiring laboratories were also severely affected (Juhary, 2015). 
In a pandemic era, the internet, big data, Artificial Intelligence, 5G, and cloud-based platforms, among other technologies, have been used for education. These changes could transform traditional, teacher-centered, and lecture-based educational activities into more student-centered, online-based activities. Likewise, education with competencies in the form of cohesiveness, teamwork is also greatly affected.

Conceptual changes in education need to be considered post-pandemic. The concept of learning is whether to go back to before the pandemic or continue learning that was carried out during the pandemic. Important thoughts in various post-pandemic countries focused on the following activities (Zhu and Liu 2020):

a. To develop an open educational platform that allows access to a variety of high-quality learning resources across educational institutions.

b. Research and evaluate current online teaching and learning models, with a particular focus on their long-term sustainability.

c. Develop staff-teacher capacity for online teaching and the capacity of professional staff to support teachers and online systems.

d. Promote collaboration between educational institutions, international organizations, the private sector, communities, and other stakeholders, to promote high-quality online learning.

At the time of the COVID-19 pandemic, education was realized. It is adapting to distance learning education, especially regarding the readiness to take distance learning education to preserve and continue the educational mission during the current or future pandemic (Lapada et al. 2020). Furthermore, a strategy for using information systems and information technology in distance learning is needed to make it more effective and efficient.

Applying information systems and information technology is an essential and long-term investment that requires enormous financial support (Sriminangga and Samopa 2017). Based on this, a structured planning strategy is needed-an information system strategic plan made to avoid failure in information system implementation. The condition and position of the institution towards the internal and external environment are known using quantitative SWOT analysis ((Longhurst et al. 2020; Wulansari \& Sfenrianto, 2019) .

Higher education worldwide requires social distancing measures that prevent face-toface teaching leading to a switch to distance learning by higher education institutions. Furthermore, a SWOT analysis carried out the analysis of the strengths, weaknesses, opportunities, and threats of using information technology in online education during the pandemic.

SWOT analysis showed internal factors that support the development of academic information systems from management and stakeholder support, governance guidelines, provision of information technology facilities, integrated information systems, and IT. 
Human resources and budget. Meanwhile, external supporting factors increased public trust, academicians, and opportunities to work better (Kaci, Prasetya, \& Sisharini 2017).

Selection of priorities by weighting higher education strategies in order to be able to compete with other universities according to the needs of stakeholders through sciencebased innovation can make using the AHP method. Data was collected through questionnaires to respondents with the criteria of management \& internal organization, academic atmosphere \& sustainability of competitiveness (Nuryanta 2018).

From these researches, SWOT analysis was used to develop strategies in developing new online resources, academic collaboration, comparison of actions taken by other institutions, including curriculum adjustments, learning methods, and assessments (Yulmaini, Sanusi, \& Yusendra 2018).

SWOT analysis and AHP have been well implemented to develop an Information system strategy in the Indonesian Navy (Wibawa \& Suharjo 2021). The SWOT analysis process is carried out with the stages of finding S-W-O-T for applying Indonesian Navy information technology, looking for the weight of the indicators for each factor, and finally determining a strategy using a combination of the SWOT and AHP methods.

Based on this background, the questions in this study are: how the education of the Indonesian Navy after the pandemic and what strategies will the Indonesian Navy take to provide better, more effective, and efficient education by using information technology after the Covid 19 pandemic?

\section{METHODS}

\subsection{Respondents and Data Collecting}

Respondents of this research were 4 Officers of Information Technology Services from the Indonesian Navy Education Institution, including the Indonesian Naval Academy, the Indonesian Navy Command and College Staff, Indonesian Navy Technology High School College, and Indonesian Navy Education and Training Command. Data was collected from the respondents using structured interviews to get the Strengths, weaknesses, opportunities, and threats data (S- W-O-T data).

\subsection{Research Steps}

The research stages using SWOT (GÜREL and TAT 2017) - AHP (Taherdoost 2018) began with the collection of interview data to determine the SWOT factors that affect the education of the Indonesian Navy, especially in the use of information technology in the post-pandemic era. The weights of the factors affecting the education of the Indonesian Navy after the pandemic in the field of information technology were analyzed using AHP by conducting pairwise comparisons to determine the importance level of each factor and the 
Rating of each factor. Furthermore, the SWOT strategy vector is compiled to formulate a priority strategy for information technology in Indonesian Navy education.

\subsection{Flow Chart}

From the research steps, it can be concluded and shown in Figure 1.

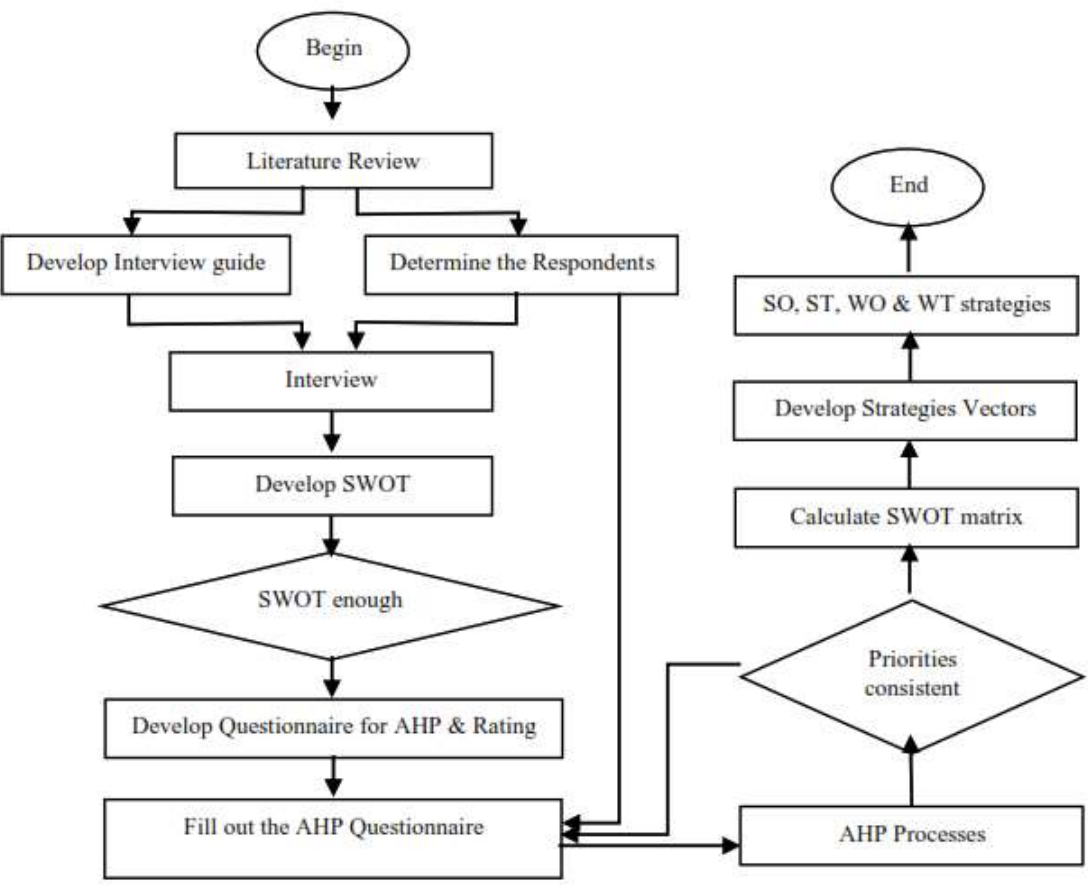

Figure 1. Flow Chart Diagram of Research

(Source: GÜREL and TAT 2017, Taherdoost 2018, Wibawa and Suharjo 2021)

\section{RESULTS AND DISCUSSION}

The data processing results include SWOT identification, calculation of the weight of the criteria for each factor, preparation of vector strategies, preparation of SO, WO, ST, and WT strategies, and the preparation of global strategies.

\subsection{S-W-O-T Identification}

Identification of SWOT analysis in Indonesian Navy Information Technology Education post-pandemic can be represented in Figure 2. There are some strengths, weaknesses for internal factors, and opportunities, threats for external factors.

\begin{tabular}{|c|c|c|}
\hline & Strength & Weakness \\
\hline $\begin{array}{l}\text { I } \\
\text { N } \\
T\end{array}$ & $\begin{array}{l}\text { 1. The culture of using information } \\
\text { technology in Indonesian Navy } \\
\text { educational institutions is getting }\end{array}$ & $\begin{array}{l}\text { 1. HR competencies in the IT field at } \\
\text { the Indonesian Navy educational } \\
\text { institutions are still lacking. }\end{array}$ \\
\hline $\begin{array}{l}\mathbf{E} \\
\mathbf{R}\end{array}$ & $\begin{array}{l}\text { better. } \\
\text { 2. Academic information system has } \\
\text { been established and utilized well }\end{array}$ & $\begin{array}{l}\text { 2. Network security at Indonesian } \\
\text { Navy educational institutions is still } \\
\text { lacking. }\end{array}$ \\
\hline $\begin{array}{l}\mathbf{N} \\
\mathrm{A}\end{array}$ & $\begin{array}{l}\text { 3. Sufficient funding from the Indonesian } \\
\text { Navy allows for comprehensive }\end{array}$ & \\
\hline
\end{tabular}




\begin{tabular}{|l|l|lrr|}
\hline $\begin{array}{l}\text { planning. } \\
\text { 4upport for IT facilities in the form of } \\
\text { network infrastructure neatly arranged } \\
\text { with sufficient internet bandwidth for } \\
\text { educational institutions }\end{array}$ & $\begin{array}{l}\text { 3. Many applications have } \\
\text { antegrated with the }\end{array}$ & $\begin{array}{l}\text { module } \\
\text { information system } \\
\text { information }\end{array}$ \\
\end{tabular}

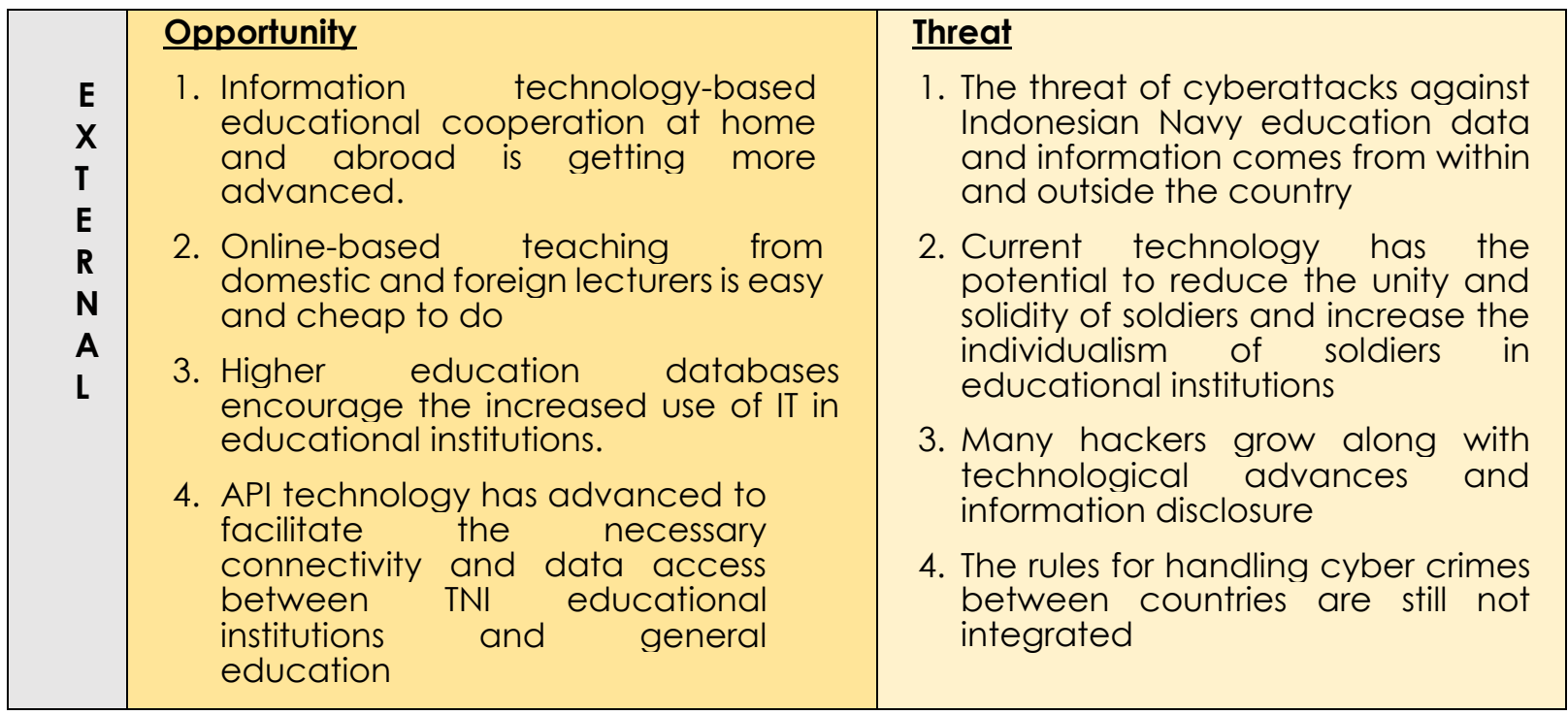

Figure 2. SWOT identification of Indonesian Navy Information Technology in Education post-pandemic

\subsection{Calculation of the weights using AHP}

Based on the IFAS and EFAS analysis results above, the weight of each indicator on IFAS and EFAS can be calculated. The weight calculation can be done using the AHP method (Taherdoost 2018). The data used base on the opinions of Indonesian Navy education experts in the pairwise comparison questionnaire. In detail, the results of the weight calculation using AHP can be presented in figure 3 and Figure 3.

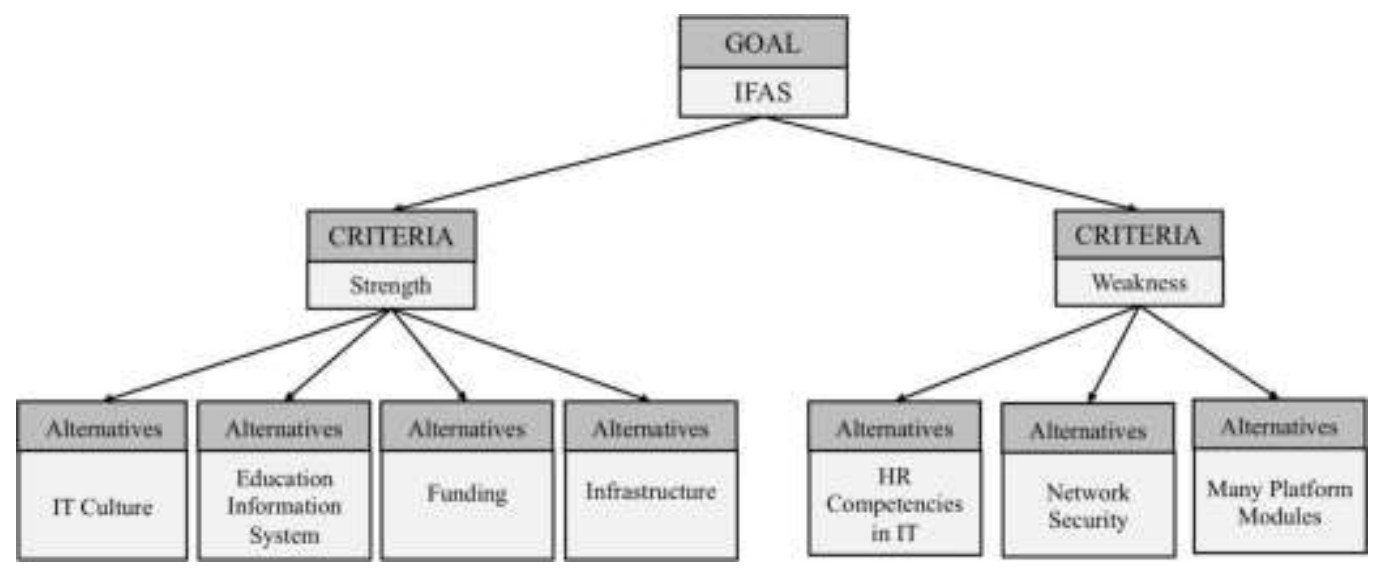

Figure 3. IFAS AHP

The calculation of weights and ratings was using a super decision application using data obtained from experts in the field of education within the Indonesian Navy using 
questionnaires. Furthermore, the calculation output in the form of the weight of each indicator on the strengths and weaknesses of the internal factors was present in Table 1.

Table 1. Weight of IFAS Indicators

\begin{tabular}{lll}
\hline & Strength Factors & Weight \\
\hline 1 & IT Culture & 0.15 \\
2 & Education Information System & 0.15 \\
3 & Funding & 0.1 \\
4 & Infrastructure & 0.1 \\
& Weakness Factors & Weight \\
1 & HR Competencies in IT & 0.2 \\
2 & Network Security & 0.15 \\
3 & Many Platforms Modules & 0.15
\end{tabular}

The calculation results in Table 1 obtained through processing with the Super decision application at an inconsistency level of 0.07 (inconsistency level is less than 0.1 ). Thus, the results of weight calculations on internal factors are consistent. Furthermore, the calculation was carried out using the AHP model for the external factor weight analysis, as Figure 4.

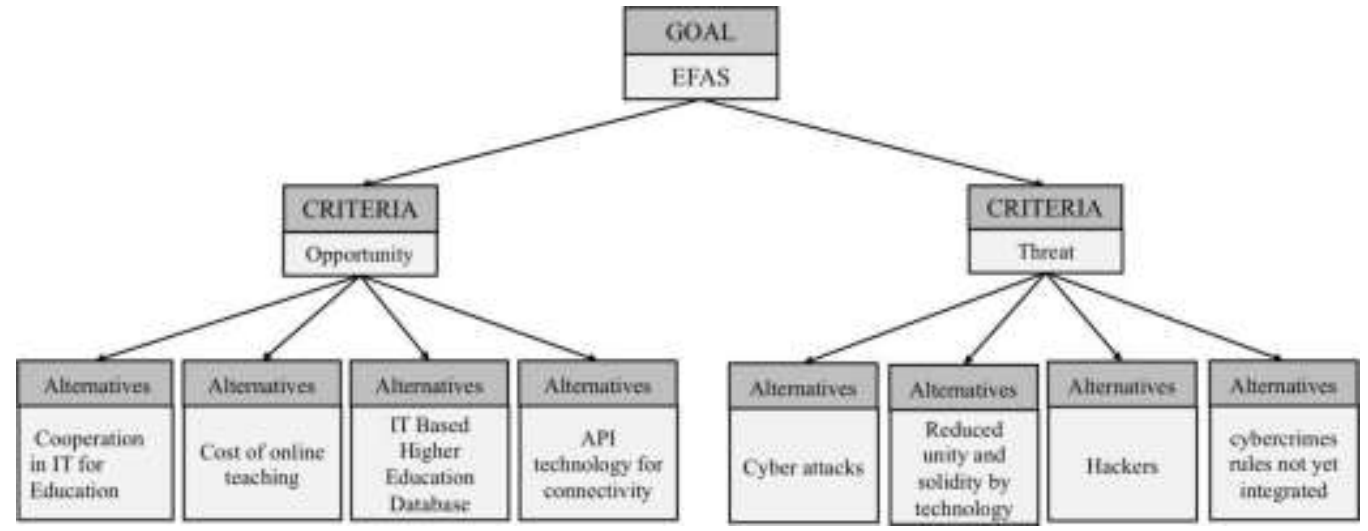

Figure 4. EFAS AHP

The calculation output in the form of the weight of each indicator on the opportunity and threat of the internal factors is presented in Table 2.

Table 2. Weight of IFAS Indicators

\begin{tabular}{lll}
\hline & Opportunity Factor & Weight \\
\hline 1 & Cooperation in IT for Education & 0.15 \\
2 & Cost of online teaching & 0.1 \\
3 & IT-Based Higher Education Database & 0.1 \\
4 & API technology for connectivity & 0.15 \\
& Threat Factor & Weight \\
1 & Cyberattacks & 0.15 \\
\hline
\end{tabular}




\begin{tabular}{lll}
\hline 2 & Reduced unity and solidity by technology & 0.15 \\
3 & Hackers & 0.1 \\
4 & Cybercrimes rules not yet integrated & 0.1
\end{tabular}

The calculation results in Table 2 were obtained through processing with the Super decision application at an inconsistency level of 0.04 (inconsistency level is less than 0.1 ). Furthermore, the results of IFAS and EFAS calculations are calculated by multiplying the Weight and rating (rating calculated as a value of 1 to 10). The results of the calculation are presented in Table 3.

Table 3. Strengths, Weaknesses, Opportunities, and Threats based on weight and rating calculations

\begin{tabular}{|c|c|c|c|c|}
\hline Factor & Indicator & $\begin{array}{l}\text { Weig } \\
\text { ht }\end{array}$ & Rating & Weight $x$ Rating \\
\hline \multirow[t]{5}{*}{ Strength } & IT Culture & 0.15 & 6.2 & 0.93 \\
\hline & Education Information System & 0.15 & 6.5 & 0.975 \\
\hline & Funding & 0.1 & 7.0 & 0.7 \\
\hline & Infrastructure & 0.1 & 6.1 & 0.61 \\
\hline & & & & 3.215 \\
\hline \multirow[t]{4}{*}{ Weakness } & HR Competencies in IT & 0.2 & 5.4 & 1.08 \\
\hline & Network Security & 0.15 & 6.0 & 0.9 \\
\hline & Many Platforms Modules & 0.15 & 5.1 & 0.765 \\
\hline & & & & 2.745 \\
\hline \multirow{5}{*}{$\begin{array}{l}\text { Opportunit } \\
\text { y }\end{array}$} & Cooperation in IT for Education & 0.15 & 7.0 & 1.05 \\
\hline & Cost of online teaching & 0.1 & 6.1 & 0.61 \\
\hline & IT-Based Higher Education Database & 0.1 & 7.2 & 0.72 \\
\hline & API technology for connectivity & 0.15 & 5.5 & 0.825 \\
\hline & & & & 3.205 \\
\hline \multirow[t]{5}{*}{ Threat } & Cyberattacks & 0.15 & 4.5 & 0.675 \\
\hline & $\begin{array}{c}\text { Reduced unity and solidity } \\
\text { by technology }\end{array}$ & 0.15 & 5.1 & 0.765 \\
\hline & Hackers & 0.1 & 5.2 & 0.52 \\
\hline & Cybercrimes rules not yet integrated & 0.1 & 5.5 & 0.55 \\
\hline & & & & 2.51 \\
\hline
\end{tabular}

\subsection{Developing SWOT Matrix}

Based on the results of the multiplication analysis of the weight and rating added to each factor, a strategy matrix can be developed, namely the vector coordinate of Strength - Opportunity (SO) was $(3.215 ; 3.205)$, the coordinate of the Vector Strength - Threat (ST) was (3.215; - 2.51), coordinate Weakness- Opportunity (WO) was (-2.745); 3.205), and the Weakness - Threat (WT) coordinate was $(-2.745 ;-2,51)$. Based on the results of the coordinate of each strategy, the resultant vector coordinate can be arranged, namely: (3.215-2.745; 
$3.205-2.51)$ or the same as $(0.47 ; 0.695)$. Furthermore, the resulting vectors can be arranged in an image with a model according to the cartesian coordinates in Figure 5.

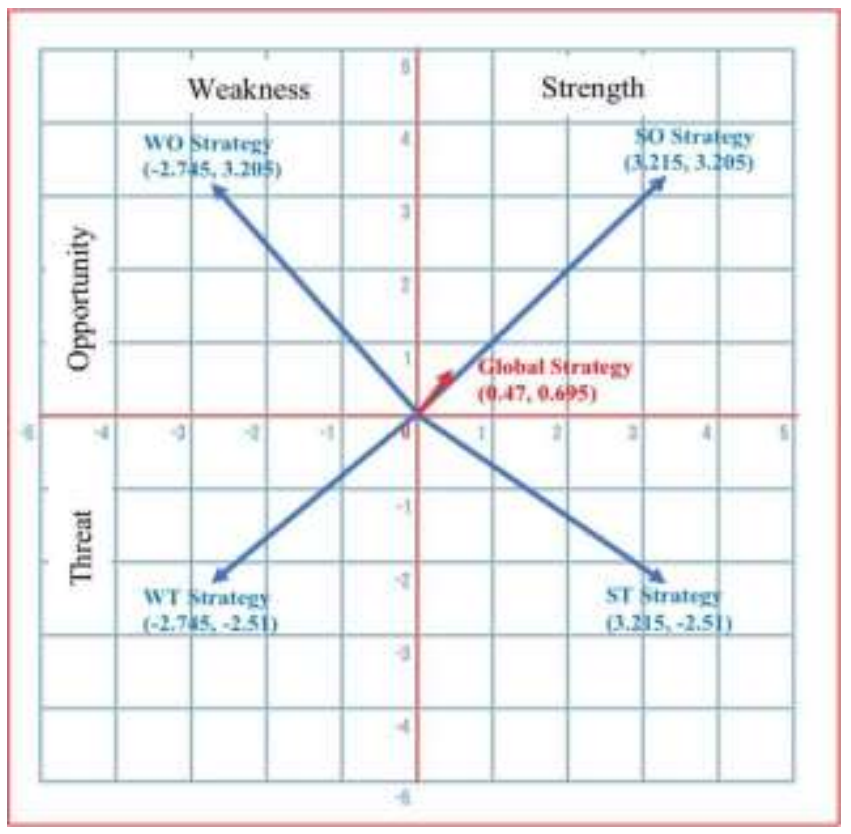

Figure 5. Vectors of SWOT strategy

\subsection{Information Technology Education Strategy Post Pandemic}

The vector image shows four strategic directions according to many quadrants, which can develop. In addition, a resultant strategy was obtained that led to an offensive strategy that would take advantage of many opportunities with the strength of the Indonesian Navy educational institution. Based on the vectors described above, an SO, ST, WO, and WT strategy and a combined strategy were developed. The results of strategy formulation can be described in Table 4.

Table 4. List of S-O strategies, W-O strategies, S-T strategies, and W-T strategies

\begin{tabular}{|c|c|c|}
\hline \multirow{7}{*}{ Internal Factors } & Opportunity & Threat \\
\hline & \multirow{3}{*}{$\begin{array}{l}\text { 1. Information technology- } \\
\text { based educational } \\
\text { cooperation domestic } \\
\text { and abroad is getting } \\
\text { more advanced } \\
\text { 2. Online-based teaching } \\
\text { from domestic and } \\
\text { foreign lecturers is easy } \\
\text { and cheap to do }\end{array}$} & \multirow{2}{*}{ 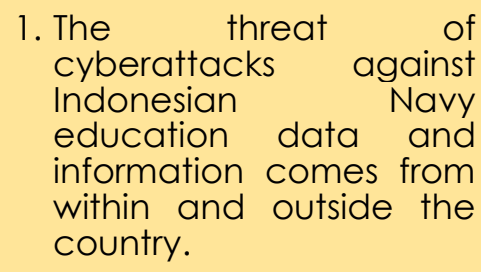 } \\
\hline & & \\
\hline & & \multirow{2}{*}{$\begin{array}{l}\text { 2. Current technology can } \\
\text { reduce the unity and } \\
\text { solidity of soldiers and } \\
\text { increase the } \\
\text { individualism of soldiers in } \\
\text { educational institutions. }\end{array}$} \\
\hline & $\begin{array}{l}\text { 3. Higher education } \\
\text { databases encourage } \\
\text { increased use of IT in } \\
\text { educational institutions. }\end{array}$ & \\
\hline & $\begin{array}{l}\text { educational institutions. } \\
\text { 4. API technology has } \\
\text { advanced to facilitate } \\
\text { the necessary }\end{array}$ & $\begin{array}{l}\text { 3. Many hackers grow } \\
\text { along with technological } \\
\text { advances and } \\
\text { information disclosure. }\end{array}$ \\
\hline & access between TNI & $\begin{array}{l}\text { 4. The rules for handling } \\
\text { cyber crimes between }\end{array}$ \\
\hline
\end{tabular}




\begin{tabular}{|c|c|c|}
\hline & $\begin{array}{l}\text { educational institutions } \\
\text { and general education }\end{array}$ & $\begin{array}{l}\text { countries are still not } \\
\text { integrated }\end{array}$ \\
\hline $\begin{array}{l}\text { Strength } \\
\text { 1. The culture of using } \\
\text { information technology in } \\
\text { Indonesian } \\
\text { Navy } \\
\text { institutions are getting } \\
\text { better. } \\
\text { 2. Academic information } \\
\text { system has } \\
\text { been established and } \\
\text { utilized well } \\
\text { 3.Sufficient funding from } \\
\text { the Indonesian Navy } \\
\text { allows for comprehensive } \\
\text { planning } \\
\text { 4.Support for IT facilities in } \\
\text { the form of } \\
\text { network infrastructure } \\
\text { was neatly arranged with } \\
\text { sufficient internet } \\
\text { bandwidth for } \\
\text { educational institutions }\end{array}$ & $\begin{array}{l}\text { S-O Strategy } \\
\text { 1.Intensifying online } \\
\text { learning in all majors/ } \\
\text { expertise at the } \\
\text { Indonesian Navy } \\
\text { Educational Institution } \\
\text { 2.Inviting internal } \\
\text { Indonesian Navy experts, } \\
\text { domestic and foreign } \\
\text { experts to become } \\
\text { extraordinary lecturers in } \\
\text { educational institutions } \\
\text { carried out online } \\
\text { 3.Integrating onaterine } \\
\text { learning materials with } \\
\text { sources from various } \\
\text { educational institutions } \\
\text { by utilizing API } \\
\text { technology }\end{array}$ & $\begin{array}{l}\text { S-T Strategy } \\
\text { 1. Optimization of the } \\
\text { education information } \\
\text { system for the education } \\
\text { process to carry out a } \\
\text { blended-based } \\
\text { education process that } \\
\text { combines online and } \\
\text { offline according to } \\
\text { educational needs } \\
\text { 2. Intensifying to takedown } \\
\text { the hacking activities } \\
\text { 3. Initiate to coordinate } \\
\text { and integrate the } \\
\text { transnational ethical } \\
\text { hacking dan } \\
\text { cybercrimes rules dan }\end{array}$ \\
\hline $\begin{array}{l}\text { Weakness } \\
\text { 1. HR competencies in the } \\
\text { IT field at the Indonesian } \\
\text { Navy educational } \\
\text { institutions are still } \\
\text { lacking. } \\
\text { 2. Network security at } \\
\text { Indonesian Navy } \\
\text { educational is still } \\
\text { institutions is } \\
\text { lacking. } \\
\text { 3. Many practical } \\
\text { module applications } \\
\text { have not been } \\
\text { integrated with the } \\
\text { education information } \\
\text { system. }\end{array}$ & $\begin{array}{l}\text { W-O Strategy } \\
\text { 1. Cooperation increases } \\
\text { Indonesian Navys' human } \\
\text { resources competence } \\
\text { through cooperation with } \\
\text { educational institutions } \\
\text { and other institutions at } \\
\text { home and abroad. } \\
\text { 2. Develop learning } \\
\text { modules and align them } \\
\text { with other institutions } \\
\text { through API technology } \\
\text { while maintaining the } \\
\text { security of information } \\
\text { systems }\end{array}$ & $\begin{array}{l}\text { W-T Strategy } \\
\text { 1. Conducting } \\
\text { human resource training } \\
\text { in educational institutions } \\
\text { to improve competence } \\
\text { in dealing with } \\
\text { cyberattacks } \\
\text { 2. Cooperation in the } \\
\text { development of learning } \\
\text { modules for learning } \\
\text { materials and exercises } \\
\text { by prioritizing information } \\
\text { security learning } \\
\text { 3. Online combined with offline } \\
\text { combled to maintain the } \\
\text { blended and solidity of the } \\
\text { unity and } \\
\text { Indonesian. } \\
\text { Navy }\end{array}$ \\
\hline
\end{tabular}

Based on the strategy formulated, the TNI AL's global education strategy dominated the SO strategy, supported and integrated with other strategies, namely the ST, WO, and WT strategies. The global strategy developed is the intensification of online learning combined with offline learning with an increasingly advanced education information system, integrating teaching material and being equipped with increasingly qualified lecturers internally to the Indonesian Navy, national and international lecturers to improve Indonesian Navy Education. In addition, it maintained the security of information systems and increased human resources' capacity in educational institutions, especially in IT, through cooperation with other related institutions. This strategy was in line with various studies that have developed 
e-learning during the pandemic and will continue in the post-pandemic period (Hermawan 2021; Saputro, Saerozi, \& Ardhiansyah, 2020; Teräs et al. 2020).

\section{CONCLUSION}

Post-pandemic education in the Indonesian Navy needs to integrate the online-based education model with face-to-face education. Online-based education, especially in theory and face-to-face learning in the discussion model, workgroup, and teamwork in military team formations, platoons, company, battalion, and skills training in using the equipment. The global strategy compiled is an intensification of the combination of online and offline learning with an increasingly advanced educational information system, combining teaching materials and being equipped with increasingly qualified teaching staff from within the Indonesian Navy, from within and outside the country to improve TNI AL education while maintaining system security. Information. Moreover, improve HR capabilities in the IT field by collaborating with other relevant agencies.

\section{REFERENCES}

Abidah, A., Hidaayatullaah, H. N., Simamora, R. M., Fehabutar, D., \& Mutakinati, L. (2020). The impact of covid-19 to Indonesian education and its relation to the philosophy of "merdeka belajar". Studies in Philosophy of Science and Education, 1 (1), 38-49.

Alea, L. A., Fabrea, M. F., Roldan, R. D. A., \& Farooqi, A. Z. (2020). Teachers' Covid-19 awareness, distance learning education experiences and perceptions towards institutional readiness and challenges. International Journal of Learning, Teaching and Educational Research, 19(6), 127-144.

Espino-Díaz, Luis et al. 2020. "Analyzing the Impact of COVID-19 on Education Professionals. Toward a Paradigm Shift: ICT and Neuroeducation as a Binomial of Action." Sustainability (Switzerland) 12(14): 1-10. https://doi.org/10.3390/su12145646

Franchi, T. 2020. "The Military Sciences against the Covid-19 Pandemic." Coleção Meira Mattos 14(May): 50. https://doi.org/10.22491/cmm.a025

GÜREL, Emet, and Merba TAT. 2017. "SWOT Analysis: A Theoretical Review." The Journal of International Social Research 10(51): 9-15. https://doi.org/10.17719/jisr.2017.1832

Hermawan, D. 2021. "The Rise of E-Learning in COVID-19 Pandemic in Private University: Challenges and Opportunities." IJORER : International Journal of Recent Educational Research 2(1): 86-95.https://doi.org/10.46245/ijorer.v2i1.77

Jury, J.. 2015. "Understanding Military Pedagogy." Procedia - Social and Behavioral Sciences 186: 1255-61. http://dx.doi.org/10.1016/j.sbspro.2015.04.104.

Kaci, A. S., Prasetya, D. A., \& Sisharini, N. (2018). Study of swot analysis on academic information system at Universitas Pattimura Ambon. Journal of electrical engineering 
and computer sciences, vol 2 number 2, dec 2017, 2(2).

Longhurst, G. J., Stone, D. M., Dulohery, K., Scully, D., Campbell, T., \& Smith, C. F. (2020). Strength, weakness, opportunity, threat (SWOT) analysis of the adaptations to anatomical education in the United Kingdom and Republic of Ireland in response to the Covid- 19 pandemic. Anatomical sciences education, 13(3), 301-311.

Narayana, N. 2018. "The Implementation of Strategic Management on Competitive Advantage in Islamic University of Indonesia (Uii) Yogyakarta." Indonesian Journal of Interdisciplinary Islamic Studies 2(1): 1-30. https://doi.org/10.20885/ijiis/vol2.iss 1 .art1

Rashid, S., \& Yadav, S. S. (2020). Impact of Covid-19 pandemic on higher education and research. Indian Journal of Human Development, 14 (2), 340-343.

Rawat, S., Boe, O., \& Piotrowski, A. (2020). Military psychology response to post-pandemic reconstruction. Jaipur: Rawat Publication.

Saputro, B., Saerozi, M., \& Ardhiansyah, F. 2020. "Philosophical Reflections: Critical Analysis of Learning Strategies for Science Practicum During the COVID-19 Pandemic." IJORER : International Journal of Recent Educational Research 1(2): 78-89. https://doi.org/10.46245/ijorer.v1i2.26

Sriminangga, N. P., \& Samopa, F. (2017). Strategic Planning of Information Systems/Information Technology at KOMINFO Department in Malang. International Journal of Education and Research, 5(1), 223-240.

Suharjo, B., \& Wibawa, A. C. (2021). Strategy of Indonesian Navy Big Data Development Using SWOT Analysis and Analytic Hierarchy Process. Journal of Information Systems and Informatics, 3(1), 201-212.https://doi.org/10.33557/journalisi.v3i1.112

Taherdoost, H.. 2018. "Decision Making Using the Analytic Hierarchy Process (AHP); A Step by Step Approach." International Journal of Economics and Management Systems 2(January 2017): 244-46. https://www.researchgate.net/publication/322887394.

Teräs, M., Suoranta, J., \& Teräs, H. (2020). Curcher M. Post-COVID-19 Education and Education Technology 'Solutionism': a Seller's Market. Postdigital Sci Educ. Postdigital Science and Education 2(3): 863-78. https://doi.org/10.1007/s42438-020-00164-x

Wulansari, T. T. \& Sfenrianto. 2019. "Strategic Plan Development of Accreditation Information System of Study Program Using Zachman Framework." International Journal of Scientific and Technology Research 8(11): 1477-85.

Yulmaini, Y., Sanusi, A., \& Yusendra, M. A. E. (2018). The Implementation of AHP for Determining Dominant Criteria in Higher Education Competitiveness Development Strategy Based on Information Technology. International Journal of Artificial Intelligence Research, 3(1). https://doi.org/10.29099/ijair.v3i1 .85

Zhu, X., \& Liu, J. (2020). Education in and after Covid-19: Immediate responses and long-term visions. Postdigital Science and Education, 2 (3), 695-699. https://doi.org/10.1007/s42438020-00126-3 